\title{
Insertion and Characterization of the cry1Ial Gene in the Potato Cultivar Spunta for Resistance to Potato Tuber Moth
}

\author{
Kelly A. Zarka \\ Department of Crop and Soil Sciences, A499B Plant and Soil Science Building, Michigan State \\ University, East Lansing, MI 48824 \\ Ria Greyling, Inge Gazendam, and Dean Olefse \\ Agricultural Research Council, Vegetable and Ornamental Plant Institute, Private Bag X293, \\ Pretoria, 0001 South Africa \\ Kimberly Felcher \\ Department of Crop and Soil Sciences, A499B Plant and Soil Science Building, Michigan State \\ University, East Lansing, MI 48824 \\ Gurling Bothma \\ Agricultural Research Council, Vegetable and Ornamental Plant Institute, Private Bag X293, \\ Pretoria, 0001 South Africa
}

\author{
Johan Brink and Hector Quemada \\ Institute of International Agriculture, 319 Agriculture Hall, Michigan State University, East Lansing, \\ MI 48824 \\ David S. Douches ${ }^{1}$ \\ Department of Crop and Soil Sciences, A499B Plant and Soil Science Building, Michigan State \\ University, East Lansing, MI 48824
}

\begin{abstract}
AdDitional INDEX words. transformation, insect, deregulation, transgenic
Abstract. Potato tuber moth (Phthorimaea operculella) is a serious pest of potatoes in tropical and subtropical regions of the world, including South Africa. The crylIal gene (from Bacillus thuringiensis) under the control of the $35 \mathrm{~S}$ cauliflower mosaic virus promoter was transformed into the potato (Solanum tuberosum) cultivar Spunta to develop a cultivar with resistance to potato tuber moth for release in South Africa. Two transformation events, 'SpuntaG2' and 'SpuntaG3', were selected and subjected to extensive molecular analyses as required by the regulatory agencies of South Africa. Southern hybridization experiments indicated that 'SpuntaG2' and 'SpuntaG3' had one and three copies of the cryIIal gene, respectively, and that the gene insertion was stable through multiple clonal generations. Furthermore, the sequence of the cryIIa1 gene in 'SpuntaG2' was compared with the known sequence of the cry1Ia1 gene and found to be identical. Polymerase chain reaction (PCR) amplification using primers for plasmid "backbone" genes demonstrated that 'SpuntaG2' contained no backbone plasmid genes, whereas 'SpuntaG3' contained several backbone plasmid genes. Therefore, further analyses were limited to 'SpuntaG2', and event-specific primers were developed for this cultivar. Analysis of the left and right border regions in 'SpuntaG2' demonstrated that the insertion of the cryIIal gene did not disrupt any functional genes nor did it create new open reading frames that encoded proteins with a significant match to the non-redundant sequence database queried by the BLASTP program. Enzymelinked immunoabsorbent assays (ELISA) tests indicate that the cry1Ia1 gene was expressed at a mean concentration of $2.24 \mu \mathrm{g} \cdot \mathrm{g}^{-1}$ fresh weight in leaf tissue and $0.12 \mu \mathrm{g} \cdot \mathrm{g}^{-1}$ fresh weight in tubers. This study demonstrates the extensive molecular characterization that is necessary to apply for deregulation of a genetically modified crop and these data have been used in a regulatory package for the general release of 'SpuntaG2'.
\end{abstract}

Potato tuber moth is a serious pest of potatoes in South Africa, causing losses as much as $\$ 5.4$ million per annum to the South African potato industry (Visser and Schoeman, 2004).

Received for publication 19 Jan. 2010. Accepted for publication 15 Apr. 2010 This project was supported by the U.S. Agency for International Development (USAID) and the Michigan Agricultural Experiment Station (MAES).

We thank the employees of Envirologix (Portland, ME), including Bruce Ferguson, Terry Goddard, Whitney King-Buker, Karen Larkin, and Joan Lawton, for their antibody production and ELISA development expertise.

${ }^{1}$ Corresponding author. E-mail: douchesd@msu.edu.
Larval mining on the plant results in the loss of leaf tissue, death of growing points, and weakening or breakage of stems (Raman, 1980), all of which can reduce yield. Tuber mining results in tubers that are not marketable or consumable and increases tuber susceptibility to infection by potato pathogens in the field and in storage (Visser, 2004).

Host plant resistance to potato tuber moth is highly desirable, and components of resistance such as glandular trichomes and acetylated glycoalkaloids (leptines) have been identified in wild potato species such as Solanum berthaultii, S. polyadenium, $S$. tarijense, and $S$. chacoense. However, attempts to introduce 
these resistance components into cultivated potato have been difficult due to linkage with undesirable traits (Kalazich and Plaisted, 1991). At present, there is no potato germplasm produced from host plant resistance breeding that has appreciable levels of resistance to potato tuber moth (Lagnaoui et al., 2000). Therefore, commercial producers rely on insecticide application, generally applied at weekly intervals, for potato tuber moth control. Control is not always satisfactory, and damage levels vary between seasons and years, depending largely on the survival of over-wintering moths and their reinfestation of newly planted fields (Visser, 2004). Most small-scale farmers cannot afford or do not have access to insecticides. Furthermore, there are no insecticides registered for use in South Africa to control potato tuber moth under storage conditions, including Bacillus thuringiensis (Bt) sprays (Nel et al., 2002). This is problematic for small-scale farmers who store their potatoes in rustic buildings or diffused light storages, which are accessible by the potato tuber moths. Thus, the only insect pest management strategy that gives consistently complete control against the potato tuber moth in the field as well as storage is the use of genetically modified (GM), insect-resistant potatoes containing the cryllal gene (Visser, 2004).

Bacillus thuringiensis is an aerobic, gram-positive soil bacterium that accumulates high levels of target-specific, insecticidal crystal proteins during sporulation. These proteins have no known detrimental effects on beneficial insects, mammals, or birds (Barton and Miller, 1993; McGaughey and Whalon, 1992). The introduction of the Bt toxin gene via genetic engineering produces host plant resistance for management of target insects. The major advantages of this delivery system are increased efficacy, reduced application costs, and minimal scouting needs compared with a conventional insecticide spray strategy (Lambert and Peferoen, 1992). Previous studies have shown that potatoes transformed with a codon-modified BtcrylIal gene (previously classified as Bt-cry $V$ ) have high levels of Bt expression, with $80 \%$ to $100 \%$ potato tuber moth mortality in detached leaf tests (Douches et al., 1998; Li et al., 1999). In an effort to develop a potato tuber moth resistant potato cultivar for humanitarian release in South Africa, a crylIal vector was developed and transformed into the potato cultivar Spunta.

The public release of any GM crop is a highly regulated event and requires the rigorous molecular characterization of the transgenic event, detailed data on protein safety, and multiple years of agronomic trials (Codex Alimentarius, 2003; Koenig et al., 2004). At the molecular level, it is first necessary to characterize the organization of the inserted genetic material, including copy number and sequence data for the inserted material and the surrounding region (Codex Alimentarius, 2003). The inserted DNA must be sequenced to verify that it has not been modified from the known sequence in the vector and for future protein safety evaluations. The surrounding genome must be sequenced to determine if an existing open reading frame (ORF) has been altered or if a new ORF has been introduced by the insertion event. This sequencing also allows for the development of event-specific polymerase chain reaction (PCR) assays that are used to monitor the presence of GM crops in the food and animal feed supply once the GM crop is released for public use. Because each insertion event must be sequenced and evaluated and because multiple integrations events can adversely affect the transgene function (Jorgensen et al., 1996), it is preferable to identify and select a GM plant with only one copy of the transgene. T-DNA vector backbone sequences are frequently incorporated into the plant genome during Agrobacterium tumefaciens-mediated transformation (De Buck et al., 2000; Oltmanns et al., 2009). Therefore, it is necessary to determine if a GM plant carries backbone sequences and to select those that do not. Once a transgenic event has been selected, one must demonstrate that the transgene and its effect are inherited in a stable manner throughout several generations.

Because of the cost involved in gaining regulatory approval for release of a GM crop, the private sector is responsible for the deregulation of nearly all of GM crops being grown worldwide. It is often necessary for public institutions/researchers to team with the private sector to pursue regulatory approval for release of a GM crop. A good example of this is the release of herbicide-tolerant soybeans (Glycine max) that were jointly developed by the Brazilian Agricultural Research Corp. (Brasília, Brazil) and the chemical company BASF®, (Ludwigshafen, Germany). They were recently given approval for release by the Brazilian Biosafety Technical Commission (BASF, 2010). Golden rice (Oryza sativa) is another example; however, it has not yet been released (Golden Rice Humanitarian Board, 2009). Currently, the only example of a publicly released GM crop is papaya ringspot virus-resistant papaya (Carica papaya) that was developed and released for the Hawaiian industry (Gonsalves, 1998).

The research presented here is the first in a series of three articles including Quemada et al. (2010) and Douches et al. (2010) documenting the extensive research necessary to apply for the release of a GM potato ('SpuntaG2') in South Africa. This project was funded by the U.S. Agency for International Development (Washington, DC) and is a collaborative effort between Michigan State University Potato Breeding and Genetics Program (East Lansing) and the Agricultural Research Council, Vegetable and Ornamental Plant Institute [(ARCVOPI), Pretoria, South Africa].

\section{Materials and Methods}

Construct DETAILS. The vector used for transformation of the potato cultivar Spunta was pSPUD5 [previously published as pBIML5 (Douches et al., 2002)], which contains a codonmodified version of the crylIal gene [previously called cry $V$ in older literature (Douches et al., 1998)] obtained from Syngenta (Basel, Switzerland). In this vector, the cryllal gene is under the control of a $35 \mathrm{~S}$ cauliflower mosaic virus (CaMV) promoter (Fig. 1) and the nptII gene is present as a selectable marker. The pSPUD5 vector was transformed into $A$. tumefaciens LBA4404.

Plant material and transformation. The potato cultivar Spunta was used for all transformations and the method of transformation was as reported in Douches et al. (1998). Rooted plantlets were transplanted into pots in the greenhouse. The leaves and tubers from these clones were used for molecular analyses and bioassays.

Determination OF COPY NUMBER. Genomic DNA of selected 'Spunta cryllal' and non-transgenic 'Spunta' plants was extracted from leaf tissue of greenhouse-grown plants according to Saghai-Maroof et al. (1984). The DNA was digested with the restriction enzyme $X b a \mathrm{I}$ (which recognizes a single restriction site between the T-borders) to assess T-DNA insert number. The resulting fragments were electrophoretically separated through a $1 \%(\mathrm{w} / \mathrm{v})$ agarose gel and transferred to a nylon membrane (Hybond N; Amersham, Little Chalfont, 
England) for Southern analysis as described by Douches et al. (1998). A digoxygenin (DIG)-labeled random-primed probe was made from a commercial kit, using DIG-11dUTP as the label, and the entire cryllal gene as the template. Labeling was done according to the manufacturer's instructions (Roche Applied Science, Indianapolis). For chemiluminescence detection, disodium 2-chloro-5-(4-methoxyspiro \{1,2-dioxetane-3,2' -(5' -chloro) tricyclo[3.3.1.13,7 ] decan\}-4-yl)-1phenyl phosphate CDP-Star (Roche) was used according to manufacturer's instructions. The hybridized membrane was then exposed to X-Ray film (Hyperfilm, Amersham) to generate autoradiographs.

STABILITY OF TRANSFORMATION EVENT. Further experiments were conducted to determine if the transformation event was stable from one clonal generation to another. The 'SpuntaG2' and 'SpuntaG3' lines used for the initial Southern analysis were maintained in tissue culture and went through 12 cycles of vegetative propagation before being exported to South Africa. The tubers imported into South Africa (SA Generation 1) were planted in the greenhouse at the ARC-VOPI and leaves (SA Generation 2) were collected for Southern analysis. Two further generations of vegetative propagation were conducted in South Africa and the leaves of SA Generation 4 were collected for Southern analysis as well. Untransformed 'Spunta' potato genomic DNA from two plants was included in the Southern blots to serve as a negative control. Genomic DNA extraction, probe preparation, and Southern analysis were conducted as indicated previously in this article. For each Southern, DNA was digested with $X b a \mathrm{I}$ (cuts once in the T-DNA region upstream of the cryllal gene) or NdeI (does not cut in the T-DNA region).

SEQUENCE COMPARISON OF INSERTED DNA AND PSPUD5 TDNA. Plant genomic DNA was extracted from leaf tissue using the DNeasy Plant Mini Kit (69104; Qiagen, Valencia, CA) according to manufacturer's instructions. The oligonucleotides used for amplification were prepared by Michigan State University's Research Technology Support Facility (East Lansing) (Table 1). PCR amplifications were conducted using Taq DNA polymerase (Invitrogen, Carlsbad,

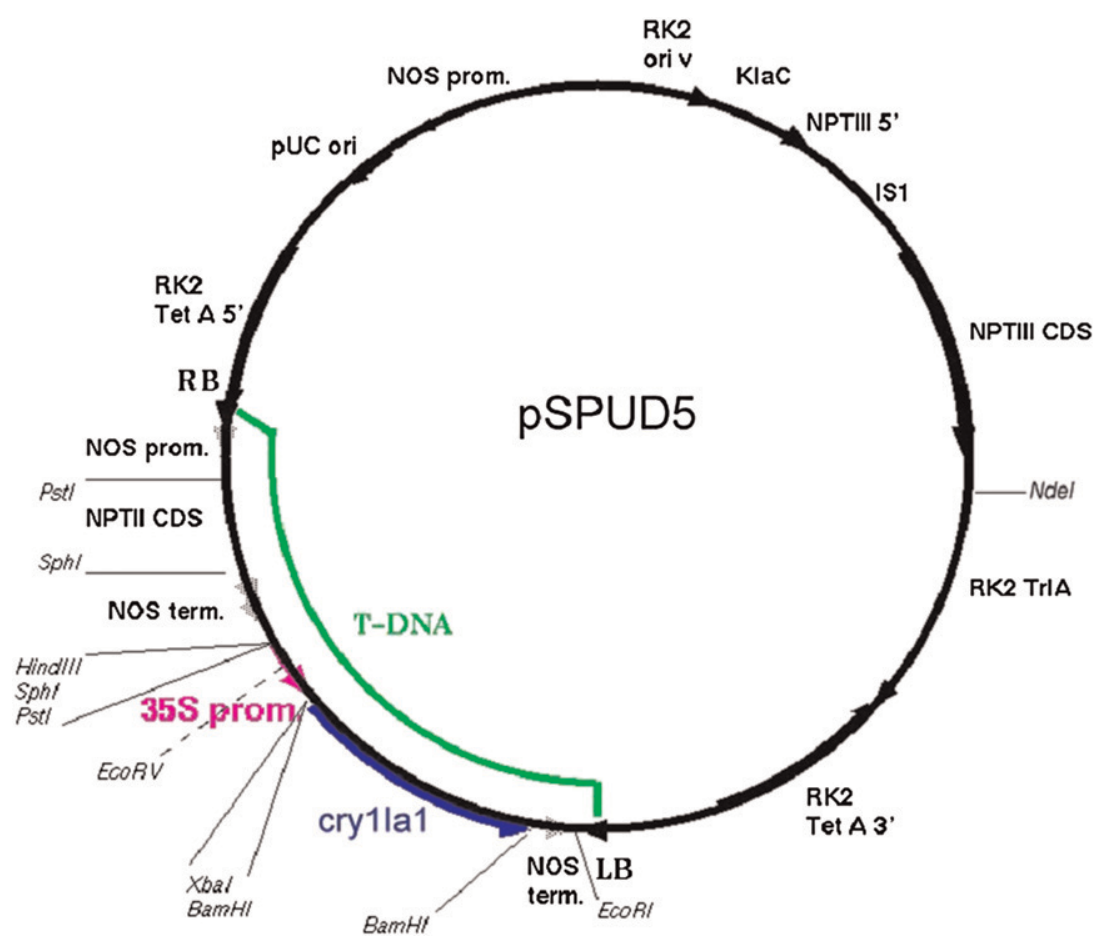

Fig. 1. Map of the pSPUD5, the Bt- crylIA1 vector construct used in transformations of potato cultivar Spunta.

Table 1. Primer sequences used in the polymerase chain reaction (PCR) for amplification of the T-DNA region in the potato cultivar SpuntaG2.

\begin{tabular}{|c|c|c|c|}
\hline Primer sets & Primer sequence & $\begin{array}{l}\text { Annealing } \\
\text { temp }\left({ }^{\circ} \mathrm{C}\right)\end{array}$ & $\begin{array}{c}\text { Band } \\
\text { size (bp) }\end{array}$ \\
\hline DAD 559 & 5' -TTC CCA CAA GCT AAA GGT CT-3' & 55 & 1000 \\
\hline DAD 490 & 5'-GAA GTA CGC CAA GCA GCT GC-3' & & \\
\hline DAD 552 & 5'-GGC CAG TGA ATT CCC GAT CTA-3' & 50 & 735 \\
\hline DAD 543 & 5'-GAC CTC CAG TTC CAC ACC AG-3' & & \\
\hline DAD 560 & 5'-CTC TCG ATG TGC AGC TGC TTG-3' & 50 & 1800 \\
\hline DAD 545 & $5^{\prime}$-CCT AAG GGC AAG AAC CAA TG-3' & & \\
\hline DAD 553 & 5'-GTG GGT CAC GAA CTT CCA GT-3' & 55 & 1100 \\
\hline DAD 545 & 5'-CCT AAG GGC AAG AAC CAA TG-3' & & \\
\hline DAD 465 & 5'-AAA CCT CCT CGG ATT CCA TTG-3' & 55 & 1100 \\
\hline DAD 554 & 5'-GAT TGT AGC GGA CCC AGC TCT CGG-3' & & \\
\hline DAD 546 & $5^{\prime}-\mathrm{TCC}$ AGG GAG TCG TGG TAG AC-3' & 55 & 1800 \\
\hline DAD 547 & 5'-TGG TTC CGG TGA TTT TGA TT-3' & & \\
\hline DAD 546 & 5'-TCC AGG GAG TCG TGG TAG AC-3' & 55 & 1800 \\
\hline DAD 547 & 5'-TGG TTC CGG TGA TTT TGA TT-3' & & \\
\hline DAD 548 & 5'-TAT CAC CGT CAC CGA CTT GA-3' & 50 & 1200 \\
\hline DAD 564 & 5'-TCT GGA TTC ATC GAC TGT GGC-3' & & \\
\hline DAD 557 & 5'-CAT GCT TAA CGT AAT TCA ACA GAA A-3' & 55 & 1200 \\
\hline DAD 549 & 5'-AGA CAA TCG GCT GCT CTG AT-3' & & \\
\hline DAD 548 & 5'-TAT CAC CGT CAC CGA CTT GA-3' & 55 & 1700 \\
\hline DAD 549 & 5'-AGA CAA TCG GCT GCT CTG AT-3' & & \\
\hline DAD 550 & 5'-ATA CTT TCT CGG CAG GAG CAA-3' & 55 & 603 \\
\hline DAD 551 & 5'-ACA AGC CGT TTT ACG TTT GG-3' & & \\
\hline
\end{tabular}

CA) according to the manufacturer's instructions. A thermal cycler (model 9600; PerkinElmer, Wellesley, MA) was programmed for a hot start $\left(95^{\circ} \mathrm{C}, 5 \mathrm{~min}\right)$ and 30 cycles of $95^{\circ} \mathrm{C}$ for $1 \mathrm{~min}$, then placed at the appropriate temperature for each primer pair for $1 \mathrm{~min}$, and $72^{\circ} \mathrm{C}$ for a $1 \mathrm{~min} 30 \mathrm{~s}$ extension, with a final extension of $72{ }^{\circ} \mathrm{C}$ for $5 \mathrm{~min}$. For clear sequencing, 
results of the PCR reaction were run on a $0.8 \%(\mathrm{w} / \mathrm{v})$ agarose gel. The fragment from each PCR reaction was purified from the agarose using a MinElute Gel Extraction Kit (28604; Qiagen) according to manufacturer's instructions. The purified fragment was sent to the Michigan State University Research Technology Support Facility for sequencing with one of the primers used in the amplification reaction. The resulting sequence was then compared with the known sequence from the original binary plasmid pSPUD5 using Merger (EMBOSS, 2000) and the two sequences were aligned.

Testing FOR PSPUD5 backbone DNA IN TRANSGENIC PLANTS. 'SpuntaG2' and 'SpuntaG3' were analyzed via PCR amplification to detect the presence/absence of three genes located in the vector construct [determined from Genbank accession number AF485783 entitled Binary vector pBI121, complete sequence (National Center for Biotechnology Information, 2009)]. Plant genomic

DNA extraction and oligonucleotide preparation were conducted as detailed previously in this article. PCR amplifications were conducted as before with the following cycling profile: $95^{\circ} \mathrm{C}, 5$ min and 30 cycles of $95^{\circ} \mathrm{C}$ for $1 \mathrm{~min}, 55^{\circ} \mathrm{C}$ for $1 \mathrm{~min}$, and $72{ }^{\circ} \mathrm{C}$ for a $1 \mathrm{~min} 30 \mathrm{~s}$ extension, with a final extension of $72^{\circ} \mathrm{C}$ for 5 $\min$. The PCR reaction products were electrophoresed through a $0.8 \%(\mathrm{w} / \mathrm{v})$ agarose gel. The three "backbone" genes of pSPUD5 and the primers used to detect their presence are listed in Table 2. The expected size of the amplified fragment is also given.

SEQUeNCE AND ANALYSIS OF THE LEFT AND RIGHT BORDER JUNCTIONS BETWEEN THE T-DNA FROM PSPUD5 AND THE GENOME OF 'SPUNTAG2'. 'SpuntaG2' genomic DNA was isolated from leaf tissue by using the DNeasy Plant Mini Kit (Qiagen) according to the manufacturer's instructions. Using this DNA as a template, a series of three PCR amplifications were conducted, using the APAgene Genome Walking Kit (BT601; Bio S\&T, Montreal, QC, Canada) to determine the flanking sequence. The gene-specific primers developed for the left border and the right border are described in Table 3. Separate reactions were done for the left border and the right border, according to the manufacturer's instructions. At the end of the third PCR, the entire reaction $(15 \mu \mathrm{L})$ containing amplified DNA was analyzed by electrophoresis on a $1 \%(\mathrm{w} / \mathrm{v})$ agarose gel (Fig. 2). One or two dominant bands ranging from 200 to 4000 bp were expected for each reaction. Two major bands were amplified from the left border and the right border region. One band was $1 \mathrm{~kb}$ in size, and the other was $400 \mathrm{bp}$. The larger band was excised from the left border and the right border lanes. The DNA was purified from the agarose gel by using the MiniElute Gel Extraction Kit (Qiagen) according to manufacturer's instructions. The sequences of the eluted DNA samples were determined by the Research Technology Support Facility group at Michigan State University using the final nested primers, GSPLB4 and GSPRB4.

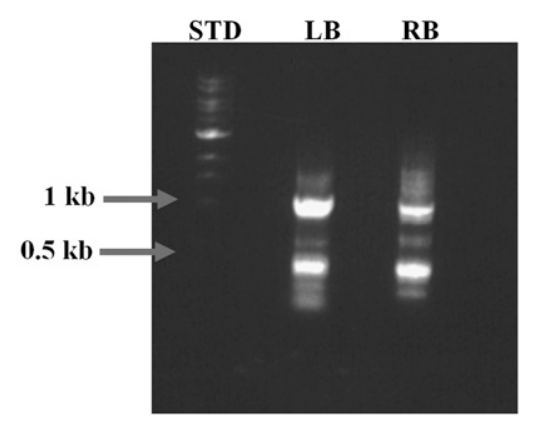

Fig. 2. The products of the APAgene Genome Walking Kit (Bio S\&T, Montreal, QC, Canada) PCR amplifications conducted on 'SpuntaG2' genomic DNA. Lane STD = molecular weight standard, lane $\mathrm{LB}=$ 'SpuntaG2' DNA amplified with GSPLB3 primers, lane RB = 'SpuntaG2' DNA amplified with GSPRB3 primers.

IDENTIFICATION OF ORF IN THE REGION OF INSERTION OF THE T-DNA IN 'SpuntaG2'. To determine whether the T-DNA inserted into an active coding sequence, the right border genomic DNA sequence and the left border (complement) sequences were joined to recreate the genomic sequence of 'SpuntaG2', which was then analyzed. Because of ambiguity regarding the source of a base (T) at the right border junction, sequences were analyzed with and without this base. This joined sequence was entered into the program ORF Finder (Stothard, 2000) to detect ORF. The default settings were used, which considered an ORF to begin with any codon, and having a length of at least 30 amino acids. The standard genetic code was used. To determine whether these amino acid sequences were identifiable proteins from potato, each of them was used as a query sequence in the BLASTP (Altschul et al., 1997) sequence matching algorithm, using the default parameters and searching the non-redundant 
protein sequence database, and the species name, Solanum tuberosum, as a delimiter.

To determine whether new ORF of concern were introduced into the region of T-DNA insertion (other than those intentionally introduced via the T-DNA itself), the sequence of the flanking regions were combined with the T-DNA sequence and subjected to analysis with ORF Finder (Tatusov and Tatusov, 2009). The identified "ORF," translated into amino acid sequences, were compared with the "ORF" predicted from the sequence of the T-DNA of pSPUD5 and the "ORF" predicted from the assembled genomic sequence analysis. Two "ORF" not matching these two criteria were identified and the amino acid sequences putatively produced by the ORF were subjected to analysis via BLASTP, with no species restriction in the search conditions.

Determination of CRY1IA1 expression in SpuntaG2. The levels of Cry1Ia1 protein present in 'SpuntaG2' leaves and tubers were determined by EnviroLogix (Portland, ME) using their commercial ELISA kit (AP075, QuantiPlate Kit for Cry1Ia1). Fresh leaf tissue $(\approx 0.054 \mathrm{~g})$ was weighed and ground in a mesh extraction pouch (ACC 021; EnviroLogix) and then further macerated after the addition of PBS extraction buffer [125 mM NaCl, $1.5 \mathrm{~mm} \mathrm{KH}_{2} \mathrm{PO}_{4}, 8 \mathrm{~mm} \mathrm{Na}_{2} \mathrm{HPO}_{4}$, and $2.5 \mathrm{~mm}$ $\mathrm{KCl}, \mathrm{pH} 7.6,0.55 \%(\mathrm{v} / \mathrm{v})$ polyoxyethylene-20 sorbitan monolaurate] at a concentration of $10 \mathrm{~mL} \cdot \mathrm{g}^{-1}$ leaf tissue. Samples were clarified by centrifugation (at $10,000 \mathrm{~g}^{\mathrm{n}}$ for $5 \mathrm{~min}$ ) and diluted 1:200 with extraction buffer. This dilution was determined in previous experiments to provide readings in the linear range of response for the assay. For the leaf tissue analysis, the mean concentration was based on seven samples from two separate 'SpuntaG2' (I6777-F and I6777-G) greenhouse-grown plants. Each of samples (F1a, F1b, F2a, F2b, G1a, G2a, and G2b) was further diluted 1:500, 1:1000, and 1:2000. For the tuber tissue analysis, the concentration was based on six separate 'SpuntaG2' (I6777-A, B, C, D, E, and H) greenhouse-grown tuber samples. For tuber tissue, the same protocol was used with the following modifications: $1 \mathrm{~g}$ of tuber tissue was weighed out and macerated in $5 \mathrm{~mL}$ of extraction buffer. Each of the samples was further diluted 1:50 and 1:100. Leaf and tuber samples were loaded onto precoated 96-well plates $(50 \mu \mathrm{L} /$ well $)$ along with negative controls and serial dilutions of protein standards. The absorbance of each well was read at $450 \mathrm{~nm}$ using a microplate reader. Concentrations of CrylIal protein were based upon standards run on the same plate, at the same time.

Development of an eVent-SPeCific PCR for 'SpuntaG2'. To develop an event-specific PCR reaction for 'SpuntaG2', two sets of primers were designed. Using the 'SpuntaG2' junction fragment sequence information previously developed, primers were designed to generate specific PCR fragments spanning the junctions on each end. Two sets of primers (IG001/IG002 and IG006/IG007) were designed to amplify the left and right flanking region, respectively (Table 4).

The primers were synthesized by Inqaba Biotechnical Industries (Pretoria, South Africa) and resuspended in double distilled $\mathrm{H}_{2} \mathrm{O}$. Three sets of PCR mixes were prepared containing $1 \mu \mathrm{M}$ each primer (three primer pairs: IG001/IG002, IG006/ IG007, and IG001/IG006), $200 \mu \mathrm{M}$ dNTPs, 1× Taq buffer
(Promega, Madison, WI), $1.5 \mathrm{~mm} \mathrm{MgCl}_{2}$, and $1 \mathrm{U}$ Taq DNA polymerase (Promega) in a total volume of $20 \mu \mathrm{L}$. Templates for each of the PCR mixes included $60 \mathrm{ng}$ of genomic DNA each from untransformed 'Spunta', transgenic 'SpuntaG2', and 'SpuntaG3' potato and a negative water control with no template DNA. The reactions were cycled on a PTC-200 minicycler (MJ Research, Waltham, MA) for 35 cycles with an annealing temperature of $55^{\circ} \mathrm{C}$. Products (the full $20-\mu \mathrm{L}$ PCR reaction) were analyzed on a $1.2 \%(\mathrm{w} / \mathrm{v})$ agarose gel. PCR products were visualized on an ultraviolet source and photographed.

\section{Results}

Based on the results of the Southern blot (Fig. 3), 'SpuntaG2' had a single band and therefore may contain a single T-DNA insert from pSPUD5. 'SpuntaG3' had three bands (3.7, 10, and $16 \mathrm{~kb}$ ), therefore, 'SpuntaG3' has at least three T-DNA's inserted into its genome. The $\mathrm{Xba \textrm {I }}$ and NdeI digestions of 'SpuntaG2' genomic DNA from SA generation 2 and SA generation 4 plants (data not shown), yielded a single, discrete hybridizing fragment of high molecular weight consistent with the single band observed in Fig. 3. The XbaI and NdeI digestions of 'SpuntaG3' genomic DNA from SA generation 2 and SA generation 4 plants (data not shown) yielded three major hybridizing fragments, consistent with the results in Fig. 3. There were no bands in the untransformed Spunta controls, as expected.

Sequence comparison demonstrated that the T-DNA sequence inserted into 'SpuntaG2' was identical to the corresponding sequence in the original pSPUD5 plasmid. Furthermore, the amplification products of 'Spunta', 'SpuntaG2', and 'SpuntaG3',

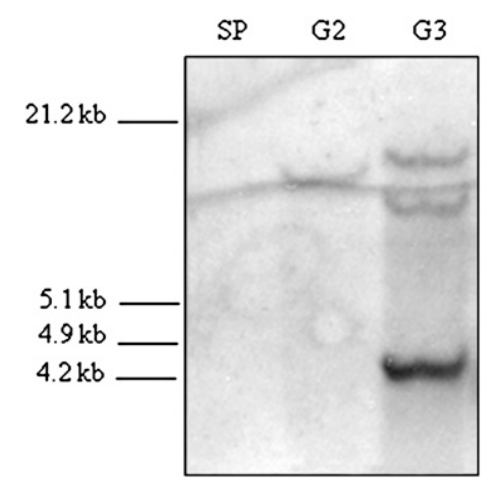

Fig. 3. Southern hybridization of $X b a I$-digested total genomic potato DNA (for determining copy number) probed with a DNA crylIA1 DIG-labeled probe. STD = DIG-Labeled DNA Molecular Weight Marker III (Roche, Indianapolis), $\mathrm{SP}=$ non-transformed 'Spunta', 'G2' = 'SpuntaG2' (single copy), G3 = 'SpuntaG3' (multiple copies). 
using primers for the genes TetA, $\operatorname{TrfA}$, and $\operatorname{TraF}$ (Fig. 4), show that none of the genes in the pSPUD5 backbone were present in 'SpuntaG2', while all of these backbone genes were present in 'SpuntaG3'. Results of Southern hybridization experiments also support this conclusion (data not shown).

Comparison of the sequenced left border with the known sequence determined that the insertion of the T-DNA into 'SpuntaG2' did not include the left border ( 26 bases) or two additional bases (AA) within the plasmid sequence. This is a commonly observed phenomenon during $A$. tumefaciensmediated transformation (Gheysen et al., 1991). Therefore, the junction between the T-DNA left border and the 'SpuntaG2' genomic DNA is as detailed in Fig. 5. Comparison of the sequenced, right border with the known sequence of the right border determined that the insertion of the T-DNA into 'SpuntaG2' did not include the right border ( $24 \mathrm{bp})$. The first base in the plasmid sequence is a $\mathrm{T}$, which is also the location of the start of the genomic DNA. Therefore, it is unknown whether this $\mathrm{T}$ remains from the T-DNA or if it is genomic DNA. The 'SpuntaG2' genomic DNA junction near the right border is as detailed in Fig. 5 where the $\mathrm{T}$ in parentheses designates the base with uncertain origin (plasmid or genome).

The identified "reading frames" in the recreated genomic sequence of 'SpuntaG2' were 1) not significantly similar to any sequenced protein from potato or 2) were only similar to potato proteins for a short segment. None of the matches revealed a functional protein. Furthermore, none of the new putative reading frames encoded proteins with a significant match (Codex Alimentarius, 2003) to the non-redundant sequence database queried by the BLASTP program.

The mean concentration of Cry1Ia1 protein in 'SpuntaG2'was determined by a commercially produced ELISA kit to be (mean $\pm \mathrm{SD}$ ) $2.24 \pm 0.55 \mu \mathrm{g} \cdot \mathrm{g}^{-1}$ fresh weight in leaf tissue and $0.12 \pm 0.04 \mu \mathrm{g} \cdot \mathrm{g}^{-1}$ fresh weight in tubers. In potato leaf tissue,

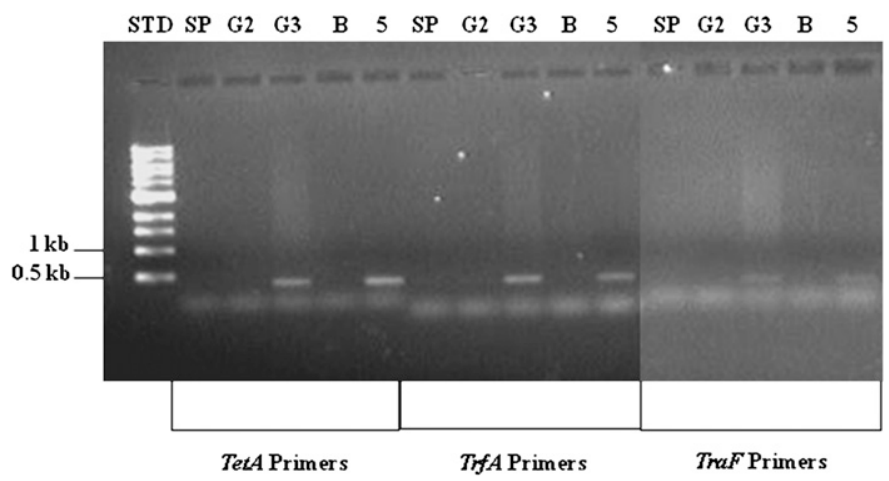

Fig. 4. PCR products obtained using primers for three genes in the pSPUD5 backbone (TetA, TrfA, and TraF), with genomic DNA of the potato cultivars Spunta, SpuntaG2, and SpuntaG3 as templates. STD = molecular weight marker, 'SP' = non-transgenic 'Spunta' DNA template, G2 = 'SpuntaG2' DNA template, G3 = 'SpuntaG3’ DNA template, B = no DNA template, $5=$ pSPUD5 DNA template.

Genomic...AATAAAAAAGTTGACGCTTAGACAACTTAATAACACATTGCGGAC...T-DNA.

T-DNA....TCGTTTCCCGCCTTCAGTTTAAACTATCAGTG(T)GAGCCATGA...Genomic.

Fig. 5. Junction sequence of the T-DNA left border (top) and the T-DNA right border (bottom) of the plasmid pSPUD5 and the flanking potato cultivar SpuntaG2 genome sequence. The bold, underlined bases are the border plasmid sequences and the " $\mathrm{T}$ " in parentheses designates the base with uncertain origin (plasmid or genome). the total protein accounts for $1.6 \%$ of the fresh weight (Stone and Lavrik, 1994), therefore, the Cry1Ia1 protein in 'SpuntaG2' fresh leaf is calculated to be $0.014 \%$ of the total protein. In potato tuber tissue, the total protein accounts for $2.1 \%$ of the fresh weight (U.S. Department of Agriculture, 2009), therefore, the Cry1Ial protein in 'SpuntaG2' tuber tissue is calculated to be $0.0006 \%$ of the total protein. Western analysis also confirmed the presence of the CrylIa1 protein in 'SpuntaG2' tissues and demonstrated it to be of the expected size [data presented in a companion article entitled, "Safety evaluations of the Cry1Ial protein found in the transgenic potato SpuntaG2" (Quemada et al., 2010)].

In 'SpuntaG2', the primer pair IG001/IG002 and the primer pair IG006/IG007 were expected to amplify a 721-bp and a 461-bp fragment, respectively, whereas, the same primer pairs would result in no amplification products in untransformed 'Spunta'. When primers IG001 and IG006 were used in combination, the genomic DNA sequence of untransformed 'Spunta', where the T-DNA was inserted, would be amplified yielding a fragment of $603 \mathrm{bp}$. 'SpuntaG2' may be hemizygous for the T-DNA insert, therefore, the primer pair IG001/IG006 may also yield a product of 603 bp in 'SpuntaG2'. The PCR product spanning the T-DNA insert in 'SpuntaG2' is too large (7037 bp), and therefore, amplification would not proceed efficiently. The expected amplification products were obtained from transgenic 'SpuntaG2' using the flanking primer sets. IG001 and IG002 amplified the 721-bp T-DNA left border flanking region (first arrow; Fig. 6, lane 2) and IG006 and IG007 amplified the 461-bp right border flanking region (second arrow; Fig. 6, lane 6). No amplification products were obtained for transgenic line 'SpuntaG3' using these primers (Fig. 6, lanes 3 and 7). This was expected because the integration of T-DNA into the potato genome occurred at an independent position for this line. When IG001 and IG006 were used as a pair, the 603-bp genomic DNA sequence at the 'SpuntaG2' insertion position was amplified in untransformed 'Spunta', 'SpuntaG2', and 'SpuntaG3' (third arrow; Fig. 6, lanes 9-11, respectively). The uninterrupted genome copy/ies in 'SpuntaG2' and 'SpuntaG3', respectively, provided the template for this amplification product.

\section{Discussion}

To develop a potato for South Africa that is resistant to potato tuber moth, the cryllal gene was transformed into the potato cultivar Spunta. Based on the standards put forth in Codex Alimentarius (2003), a series of experiments were designed to select a transformation event or events that meet the specified requirements. After extensive molecular characterization of two transgenic events ('SpuntaG2' and SpuntaG3'), 'SpuntaG2' was determined to be a good candidate to pursue for deregulation. Southern analysis revealed that 'SpuntaG2' contained a single copy of the cryllal gene, which is desirable. In contrast, 'SpuntaG3' had three copies of the gene. These results were independently verified in South Africa with additional Southern analyses of 'SpuntaG2', 'SpuntaG3', and two clonal generations (SA generation 2 and SA generation 4) of each of these transformed lines (data not shown). Taken together, these Southern blot results 


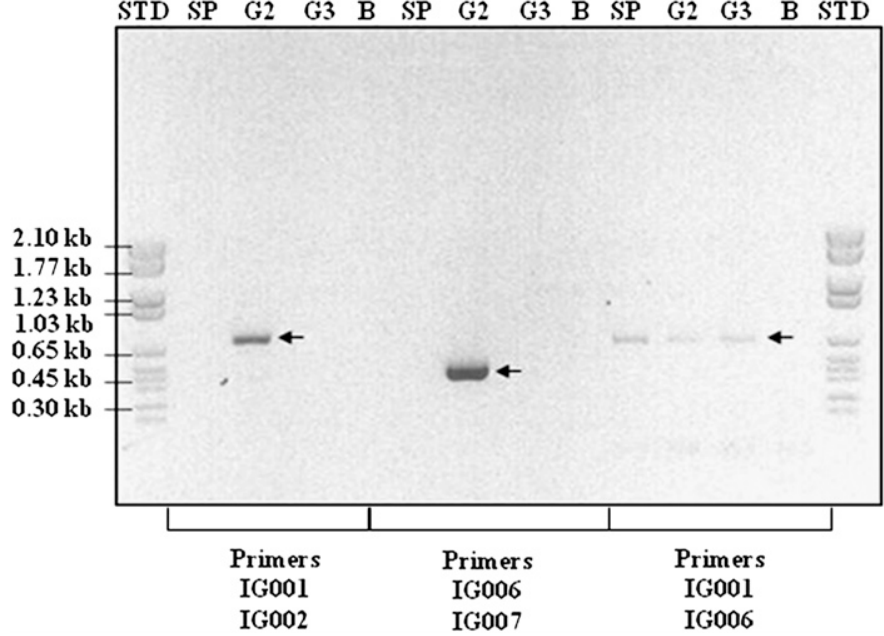

Fig. 6. Event-specific PCR for the potato cultivar SpuntaG2. PCR analysis of event-specific primers on 'Spunta,' 'SpuntaG2', and 'SpuntaG3' genomic DNA. Lane STD = molecular weight marker, 'SP' = non-transgenic 'Spunta' DNA template, G2 = 'SpuntaG2' DNA template, G3 = 'SpuntaG3' DNA template, B = no DNA template. The primer sets used were IG001 and IG002, IG006 and IG007, and IG001 and IG006.

support the conclusion that a single T-DNA insert from pSPUD5 was integrated into the 'Spunta' genome in 'SpuntaG2' and that this insertion has been stable through multiple clonal generations. In addition, progeny from crosses between 'SpuntaG2' and non-transgenic lines segregate $1: 1$ for the presence/absence of the crylIal gene (data not shown), further supporting the conclusion that 'SpuntaG2' contains only one copy of the T-DNA insert.

Sequencing of the crylIal gene in 'SpuntaG2' indicated that the gene was unchanged during the transformation process. Furthermore, PCR and Southern analysis demonstrated that none of the vector backbone sequence was incorporated into 'SpuntaG2' in contrast to 'SpuntaG3', which carried sequences from at least three backbone genes. The junction between the T-DNA and the genome of 'SpuntaG2' was sequenced up to 714 bases from the left border and 921 bases from the right border to determine 1) whether the T-DNA inserted into a coding sequence of potato, and 2) whether the T-DNA produced a reading frame that might produce a new protein. The sequence analysis supported the conclusion that no functional genes were interrupted or otherwise affected by the insertion of the T-DNA from pSPUD5. Furthermore, none of the putative "new" proteins, if in fact they are produced, matches any protein that raises a safety concern. The junction-site sequencing also allowed for the development of event-specific PCR primer sets (IG001/IG002 and IG006/IG007) that amplify only the 'SpuntaG2' transformation event.

The concentration of Cry1Ia1 protein in 'SpuntaG2' leaf tissue $(0.14 \%$ of the total protein) falls within the range of previously reported expression levels $(0.01 \%$ and $0.6 \%$ of total leaf protein) for codon-optimized $\mathrm{Bt}$ genes (Schuler et al., 1998). The concentration of Cry1Ial protein in 'SpuntaG2' tuber tissue $(0.0006 \%$ of the total protein) is well below levels reported by Monsanto (Chesterfield, MO) $(0.07 \%$ for total foliage protein and $0.005 \%$ of total tuber protein) when they used an enhanced version of the 35SCaMV promoter to express the Bt gene cryIIIa in the potato cultivars Atlantic and Superior
(Stone and Lavrik, 1994). The low levels of Cry1Ia1 protein in 'Spunta G2' tissues gave cause for concern regarding the efficacy of this cultivar against potato tuber moth, particularly in storage where the tubers might be susceptible. However, initial detached leaf bioassays demonstrated that 'SpuntaG2' was resistant to potato tuber moth in the laboratory ( $\mathrm{Li}$ et al., 1999). Therefore, additional field testing was initiated in South Africa in cooperation with ARC-VOPI and with permission from national regulators. The results of these efficacy and agronomic studies are part of a comprehensive regulatory package for 'SpuntaG2' that has been submitted to the South African government for approval and have also been submitted as a companion article to the current research (Douches et al., 2010). An additional companion article that provides a safety assessment of the CryIlal and NPTII proteins found in 'SpuntaG2' has also been submitted for publication (Quemada et al., 2010).

If approved, this will be the first publicly funded, GM crop to enter Africa. Currently, other approved GM crops such as cotton (Gossypium hirsutum), maize (Zea mays), and soybean events are owned and produced by seed companies in the private sector. The 'SpuntaG2' potato would provide commercial farmers with a safe and effective alternative to chemical pesticide use for the control of potato tuber moth. Because 'SpuntaG2' is targeted for humanitarian release, it would be available to small-scale farmers royalty free and would provide them with a means to control potato tuber moth in the field and storages. The combined result would be to reduce pest management costs and to have a more positive impact on the people and environment of South Africa.

\section{Literature Cited}

Altschul, S., T. Madden, A. Schäffer, J. Zhang, Z. Zhang, W. Miller, and D. Lipman. 1997. Gapped BLAST and PSI-BLAST: A new generation of protein database search programs. Nucleic Acids Res. 25:3389-3402.

Barton, K.A. and M.J. Miller. 1993. Production of Bacillus thuringiensis insecticidal proteins in plants, p. 297-315. In: S.D. Kung and R. Wu (eds.). Transgenic plants, Vol. 1. Academic Press, New York. BASF. 2010. BASF and Embrapa's Cultivance ${ }^{\circledR}$ soybeans receive approval for commercial cultivation in Brazil. 1 Mar. 2010. <http:// www.basf.com/group/pressrelease/P-10-148>.

Codex Alimentarius. 2003. Guideline for the conduct of food safety assessment of foods derived from recombinant-DNA plants CAC/GL 45-2003. 23 Feb. 2010. <http://www.codexalimentarius.net/search/ advancedsearch.do>.

De Buck, S., C. De Wilde, M. Van Montagu, and A. Depicker. 2000. T-DNA vector backbone sequences are frequently integrated into the genome of transgenic plants obtained by Agrobacterium-mediated transformation. Mol. Breed. 6:459-468.

Douches, D., A. Westedt, K. Zarka, and E.J. Grafius. 1998. Transformation of $C r y V-B t$ transgene combined with natural resistance mechanisms for resistance to tuber moth in potato (Solanum tuberosum L.). HortScience 33:1053-1056.

Douches, D., W. Li, K. Zarka, J. Coombs, W. Pett, E. Grafius, and T. El-Nasr. 2002. Development of Bt-cry5 insect resistant potato lines Spunta-G2 and Spunta-G3. HortScience 37:1103-1107.

Douches, D., W. Pett, D. Visser, J. Coombs, K. Zarka, G. Bothma, J. Brink, H. Quemada, and K. Felcher. 2010. Field and storage evaluations of 'SpuntaG2' for resistance to potato tuber moth and agronomic performance. J. Amer. Soc. Hort. Sci. 135:333-340.

EMBOSS. 2000. Mobyle at Pastuer; Merger. 9 Apr. 2010. <http:// mobyle.pasteur.fr/cgi-bin/portal.py? form $=$ merger $>$.

Gheysen, G., R. Villarroel, and M. Van Montagu. 1991. Illegitimate recombination in plants: A model for T-DNA integration. Genes Dev. 5:287-297. 
Golden Rice Humanitarian Board. 2009. Regulation of transgenic rice: Regulatory issues. 9 Apr. 2010. <http://www.goldenrice.org/ Content2-How/how4_regul.html>.

Gonsalves, D. 1998. Control of papaya ringspot virus in papaya: A case study. Annu. Rev. Phytopathol. 36:415-437.

Jorgensen, R.A., P.D. Cluster, J. English, Q. Que, and C.A. Napoli. 1996. Chalcone synthase cosupression phenotypes in petunia flowers: Comparison of sense vs. antisense and single-copy vs. complex T-DNA sequences. Plant Mol. Biol. 31:957-973.

Kalazich, J.C. and R.L. Plaisted. 1991. Association between trichrome characters and agronomic traits in Solanum tuberosum (L.) $\times S$. berthaultii (Hawkes) hybrid. Amer. Potato J. 68:833-847.

Koenig, A., A. Cockburn, R.W.R. Crevel, E. Debruyne, R. Grafstroem, U. Hammerling, I. Kimber, I. Knudsen, H.S. Kuiper, A.A.C.M. Peijnenburg, A.H. Penninks, M. Poulsen, M. Schauzu, and J.M. Wal. 2004. Assessment of the safety of foods derived from genetically modified (GM) crops. Food Chem. Toxicol. 42:10471088.

Lagnaoui, A., V. Canedo, and D.S. Douches. 2000. Evaluation of Btcryllal (cryV) transgenic potatoes on two species of potato tuber moth, Phthorimaea operculella and Symmetrischema tangolias (Lepidoptera: Gelechiidae) in Peru, p. 117-121. In: Program Report 1999-2000. International Potato Center, Lima, Peru.

Lambert, B. and M. Peferoen. 1992. Insecticidal promise of Bacillus thuringiensis: Facts and mysteries about a successful biopesticide. Bioscience 42:112-122.

Li, W., K. Zarka, D.S. Douches, J.J. Coombs, W.L. Pett, and E.J. Grafius. 1999. Co-expression of potato PVY ${ }^{0}$ coat protein gene and cryV-Bt genes in potato (Solanum tuberosum L.). J. Amer. Soc. Hort. Sci. 124:218-223.

McGaughey, W.H. and M.E. Whalon. 1992. Managing insect resistance to Bacillus thuringiensis toxins. Science 285:1451-1454.

National Center for Biotechnology Information. 2009. Genbank overview. 16 Apr. 2010. <http://www.ncbi.nlm.nih.gov/genbank/>.

Nel, A., M. Krause, and N. Khelawanlall. 2002. A guide for the control of plant pests. 39th ed. National Department of Agriculture,
Directorate of Agricultural Production Inputs, Pretoria, South Africa.

Oltmanns, H., B. Frame, L.-Y. Lee, S. Johnson, B. Li, K. Wang, and S. Gelvin. 2009. Generation of "backbone" free, low transgene copy plants by launching T-DNA from the Agrobacterium chromosome. 1 Mar. 2010. <http://hdl.handle.net/10101/npre.2009.3497.1>.

Quemada, H., K. Zarka, W. Pett, G. Bothma, K. Felcher, H. Mirendil, M. Koch, J. Brink, and D. Douches. 2010. Safety evaluations of the Cry1Ia1 protein found in the transgenic potato 'SpuntaG2'. J. Amer. Soc. Hort. Sci. 135:325-332.

Raman, K.V. 1980. Potato tuber moth. Tech. Info. Bul. 3. International Potato Center, Lima Peru.

Saghai-Maroof, M.A., K.M. Soliman, R.A. Jorgensen, and R.W. Allard. 1984. Ribosomal DNA spacer-length polymorphisms in barley: Mendelian inheritance, chromosomal location, and population dynamics. Proc. Natl. Acad. Sci. USA 81:8014-8018.

Schuler, T.H., G.M. Poppy, B.R. Kerry, and I. Denholm. 1998. Insectresistant transgenic plants. Trends Biotechnol. 16:168-175.

Stone, T.E. and P.B. Lavrik. 1994. Petition for determination of nonregulated status. Potatoes expressing the colorado potato beetle control protein of Bacillus thuringiensis subsp. tenebrionis. Petition no. 94-257-01. U.S. Dept. Agr, Washington, DC.

Stothard, P. 2000. Sequence manipulation suite. 2 Feb. 2010. $<$ http:// www.bioinformatics.org/sms/index.html>.

Tatusov, T. and R. Tatusov. 2009. Open reading frame reader. 23 Feb. 2010. <http://www.ncbi.nlm.nih.gov/projects/gorf/>.

U.S. Department of Agriculture. 2009. Nutrient data bank, Food composition: Potato, flesh and skin, raw. 23 Feb. 2010. <http:// www.nal.usda.gov/fnic/foodcomp/cgi-bin/list_nut_edit.pl $>$.

Visser, D. 2004. The potato tuber moths, Phthorimaea operculella (Zeller), in South Africa: Potential control measures in nonrefrigerated store environments. PhD Thesis. University of Pretoria, Pretoria, South Africa.

Visser, D. and A.S. Schoeman. 2004. Flight activity patterns of the potato tuber moth, Phthorimaea operculella (Zeller) (Lepidoptera: Gelechiidae). African Entomol. 12:135-139. 